\title{
L'interoperabilità tra software BIM e gaming. Una sperimentazione aperta per l'architettura storica
}

\author{
Valeria Cera
}

\section{Abstract}

Il contributo presenta una piccola ricerca condotta nell'ambito di una tesi di laurea sul tema estremamente contemporaneo della interoperabilità tra modelli HBIM, relativi a manufatti del patrimonio storico, e software derivanti dal gaming, per la loro interrogazione e fruizione. Attraverso l'attuazione di un protocollo che scandisce le attività progressive dalla raccolta dati alla fruizione degli stessi, testato sul campione di studio del complesso di Sant'Antonio a Nocera, l'indagine ha validato l'interoperabilità tra i programmi di authoring BIM più accreditati (Autodesk Revit) e il game engine Unreal, oggi il più potente del settore. L'interesse dello studio è enucleato nella volontà di dare risposta a tre domande basilari: I. Quali sono, nella grande quantità e varietà di informazioni che sottendono a un patrimonio storico stratificato, le potenziali risorse da raccogliere e disseminare, in funzione degli obiettivi? 2. In che modo strutturare le informazioni in accordo alle necessità? 3. Perché il connubio tra i sistemi indagati costituisce una risorsa nel processo di conoscenza, analisi e comunicazione del patrimonio?

\section{Parole chiave}

interoperabilità, modelli informativi, HBIM,VR, Unreal Engine.

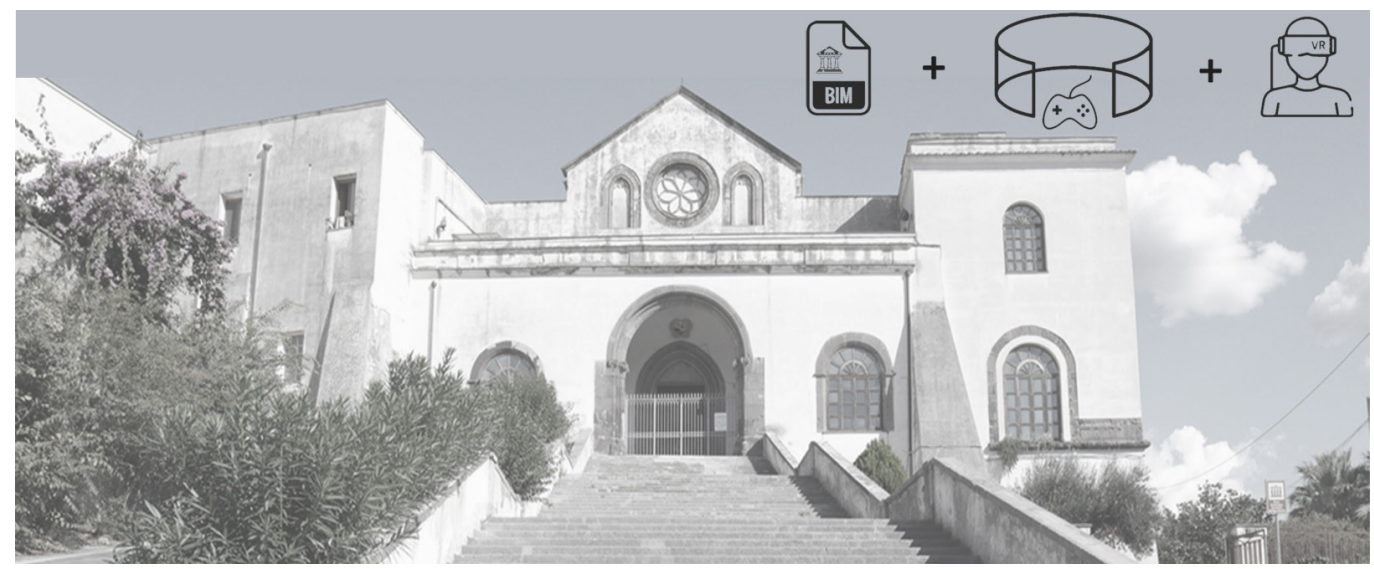




\section{Introduzione}

Secondo i dati riportati dall'Unesco, il 70\% del territorio nazionale è classificato Patrimonio Storico il che rende l'Italia il paese con il più grande patrimonio culturale a livello mondiale. Questi dati, lungi dall'essere un banale report pubblicitario, mostrano, al contrario, quanto sia necessario per tutti gli attori che esercitano le proprie competenze nel campo del Cultural Heritage, conoscere, conservare, gestire e divulgare il patrimonio quale testimonianza della nostra personalissima civiltà.

Su tale consapevolezza trova fondamento lo sviluppo metodologico di modelli Heritage-BIM concepiti come sistemi informativi che strutturano intorno ad oggetti parametrici intelligenti la quantità di informazioni eterogenee che connotano specificamente il tessuto storico. Se da un lato è diffusa la consapevolezza delle difficoltà di codificazione di smart-objects precipui per la caratterizzazione dei manufatti storici [Santoni 202I; Brusaporci 20 I9]; dall'altro, sono manifeste le possibilità sottese alla costituzione di archivi di dati capaci di collezionare, organizzare e gestire livelli conoscitivi molteplici, agganciati alla espressione spaziale digitale del costruito.

Allo stesso tempo, lo sviluppo esponenziale dell'industria 4.0 e la sempre più diffusa familiarità con gli strumenti digitali, ha trasferito l'impiego di tecniche proprie dell'Extended-Reality anche al dominio del $\mathrm{CH}$ tanto che le stesse piattaforme BIM hanno implementato plugin per supportare visualizzazioni in AR e VR. In tal modo, l'applicazione dell' $X R$ ai modelli HBIM [Banfi 2020; Davidson 2020; Empler 2019] è diventato un segmento di ricerca su cui numerosi studi si stanno concentrando, orientati ad individuare i processi più idonei per la visualizzazione e interrogazione delle informazioni che accompagnano la geometria del gemello digitale. La disamina della letteratura specifica evidenzia che non sempre il risultato offerto da codeste applicazioni è coerente con gli obiettivi iniziali laddove per rendere fluida la visione dei contenuti digitali, i sistemi $X R$ impongono una semplificazione geometrica e quindi grafica del modello con conseguente potenziale perdita del contenuto informativo associato. In aggiunta, le modalità di interazione offerte sono spesso basilari e non personalizzabili.

Per questi motivi si sta sempre più diffondendo il ricorso a programmi derivanti dal mondo del gaming per beneficiare dell'alto livello di fotorealismo delle scene digitali nonché delle svariate possibilità di conferire un carattere personale e non standardizzato alla interattività [Pulcrano 2020; Di Luggo 2020]. I motori di gioco, come Unity o Unreal Engine, sono di fatto sistemi che racchiudono dispositivi grafici, fisici e di intelligenza artificiale capaci di simulare la realtà con una aderenza ai processi fisici e percettivi che la connotano tale da far dimenticare, a volte, il confine molto labile tra mondo simulato e mondo reale. Inoltre, a differenza dei tradizionali motori di rendering, rendono possibili animazioni, simulazioni, interazioni spinte grazie alla progettazione - mediante i comuni linguaggi di programmazione - della scena che non sarà più statica ma resa dinamica. Questo aspetto è fondamentale perché, in funzione degli obiettivi che portano un utente ad accostarsi ad una espressione del patrimonio costruito e alla sua replica digitale, i livelli di conoscenza 'erogabili' devono necessariamente essere strutturati in modo da adattarsi alle necessità e alle richieste dell'interlocutore che non obbligatoriamente è uno specialista.

Da queste premesse è maturata la ricerca che il contributo presenta [ I], incentrata sulla verifica della reale interoperabilità tra modelli HBIM strutturati in Autodesk Revit, tra i programmi di authoring BIM più accreditati, e il game engine Unreal, oggi il più potente del settore.

Attraverso l'attuazione di un protocollo che scandisce le attività progressive dalla raccolta dati alla fruizione degli stessi, testato sul campione di studio del complesso di Sant'Antonio a Nocera, lo studio prova a dare risposta a tre domande basilari: I. Quali sono, nella grande quantità e varietà di informazioni che sottendono a un patrimonio storico stratificato, le potenziali risorse da raccogliere e disseminare, in funzione degli obiettivi? 2. In che modo strutturare le informazioni in accordo alle necessità? 3. Perché il connubio tra i sistemi indagati costituisce una risorsa nel processo di conoscenza, analisi e comunicazione del patrimonio? 


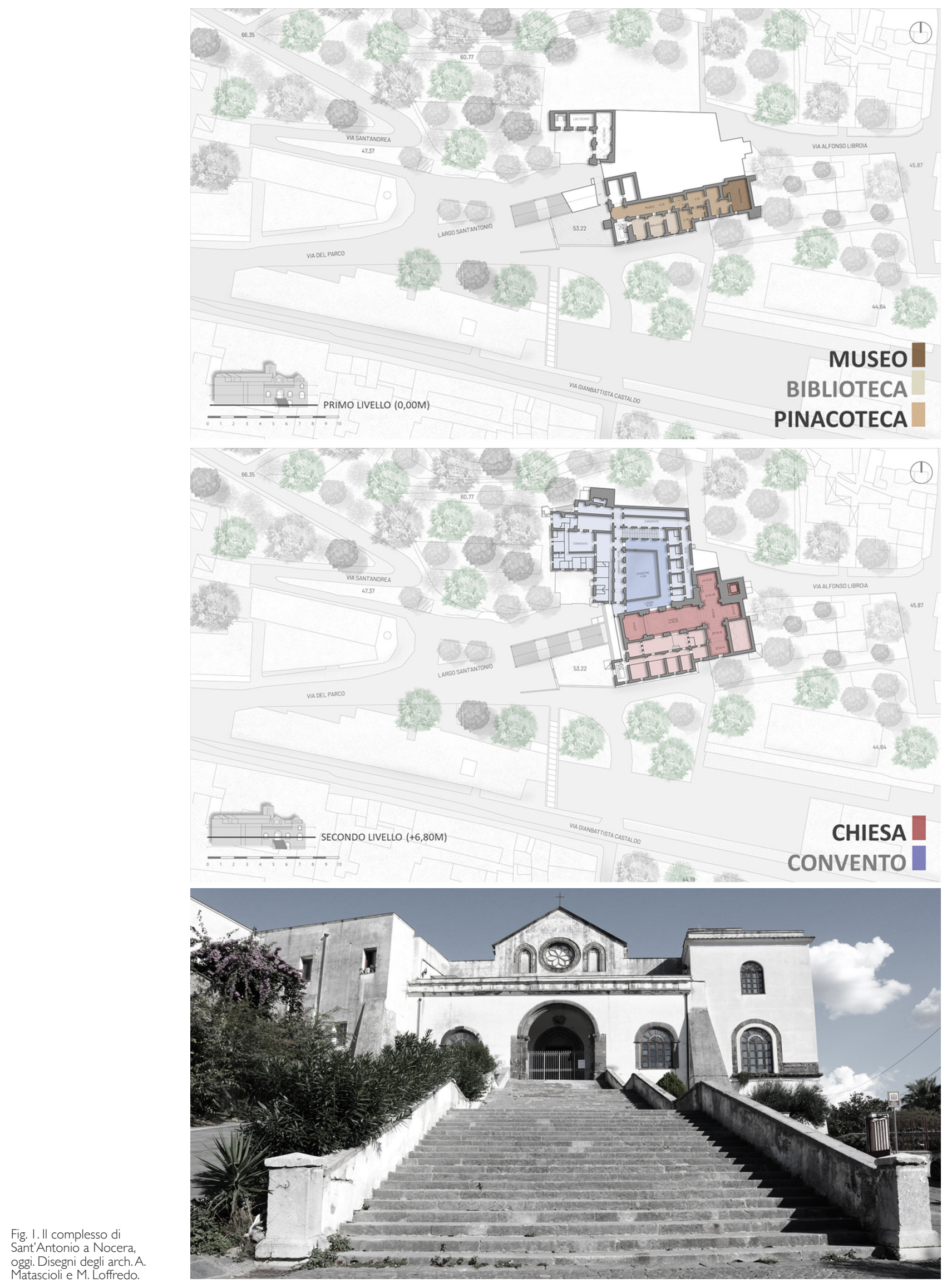




\section{Caso studio: il complesso di Sant'Antonio a Nocera}

Situato nel comune di Nocera Inferiore (SA), il complesso di Sant'Antonio sorge ai piedi della Collina del Parco, ricadendo nel quartiere Casale della Pietraccetta il cui sviluppo nel tempo è strettamente legato alla presenza del complesso religioso.

La fondazione della fabbrica, inserita in un contesto architettonico di pregio data la presenza nelle immediate vicinanze delle più importanti e antiche emergenze della città, ha origini trecentesche. II primo impianto fu realizzato tra il 1256 e il I 290 per volontà della famiglia Filangieri e rimase grossomodo lo stesso sino al primo restauro (I563-1580) e ai primi ampliamenti registrati tra il XV e il XVII secolo su commissione della famiglia dei Carafa. Le trasformazioni più significative subite dal complesso sono avvenute a seguito della soppressione dell'Ordine con la conversione del convento in caserma con Regio Decreto del I 808. Con l'avvento delle Grandi Guerre il complesso continuò a mantenere il suo ruolo strategico e ad essere oggetto di numerose modifiche fino a quando, con il ritorno dei frati nel $195 \mathrm{I}$, ritornò a svolgere il suo ruolo di polo religioso e culturale accogliendo anche nuove funzioni come la biblioteca dell'Agro Nocerino. I frati avviarono una serie di restauri volti a liberare il convento dalle alterazioni arvenute nel tempo ma, a seguito del terremoto del 1980, il complesso riportò gravi danni al sistema di coperture. L'evento tragico però diede l'avvio a una serie di operazioni di consolidamento e restauro le quali hanno fatto riaffiorare le antiche tracce stratificate e sepolte nel tempo.

Attualmente il complesso si sviluppa su più livelli.

Il piano posto alla quota stradale ospita il museo, la biblioteca e la pinacoteca.

Al secondo livello è possibile distinguere: la chiesa, a croce tipicamente latina, ad unica navata, con transetto e cappelle laterali nei bracci; il convento vero e proprio con gli alloggi dei frati; il chiostro cinquecentesco dove si svolge la vita dei frati e dei novizi (fig. I).

Lo sviluppo storico del complesso, con la sua conseguente articolazione e variazione morfologica, ha suggerito, per la validazione della ricerca, di porre l'attenzione sull'ambiente della chiesa monastica. Di tutte le parti del complesso essa, infatti, rappresenta il primo impianto costruttivo e al contempo il nucleo che più di tutti ha subito trasformazioni significative. Un vero e proprio palinsesto che, per le succitate caratteristiche, è risultato essere interessante da indagare poiché fornisce l'occasione di misurarsi con la varietà dei contenuti informativi che è possibile associare ai modelli digitali, anche in rapporto alle diverse epoche storiche, $\mathrm{e}$ con le modalità più opportune di trasmissione e consultazione di dati così multilivello.

\section{Dal modello HBIM alla interrogazione della scena virtuale}

Come anticipato, le motivazioni della ricerca risiedono nella volontà di testare il fattivo dialogo tra sistemi che di per sé funzionano in maniera autonoma e singola così da originare una 'macchina' più complessa data dalla 'addizione' degli ingranaggi puntuali che la compongono. Per cui, il clone digitale parametrico non è più un modello 3D informativo interrogabile da esperti così come la VR e i motori di gioco non sono più funzionali alla sola e semplice visualizzazione.

II risultato atteso dalla interconnessione di codesti sistemi è una banca dati grafico-informativa, predisposta per il caso di studio, in cui il modello tridimensionale, strutturato in logica HBIM, è progettato come ambiente virtuale in cui i livelli conoscitivi associati alle componenti spaziali sono fruibili e interrogabili in modo totalmente interattivo e immersivo, declinabili in funzione dell'utente cui si rivolge e agli obiettivi della interrogazione.

Il perseguimento dell'obiettivo è stato condotto impostando un workflow, applicato alla chiesa del complesso di Sant'Antonio, articolato nelle fasi di: raccolta dei dati; restituzione dei dati; implementazione dei dati; fruizione dei dati.

La prima fase è stata sostanziata da una ricca ricerca di archivio accompagnata dalla registrazione dei dati morfo-metrici della chiesa condotta con tecniche di rilievo integrate di tipo tradizionale diretto e image-based. La disamina critica di tutti i dati eterogenei raccolti, approfondita con il processamento in specifici software di SfM di un primo modello discretizza- 


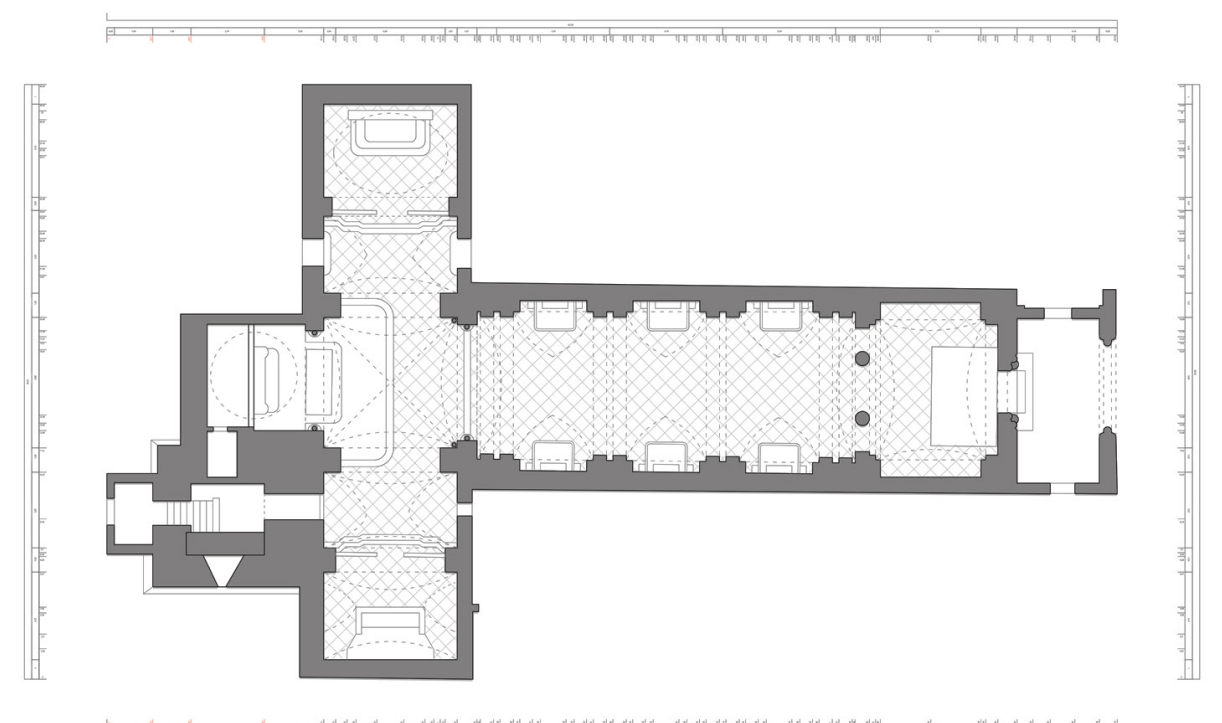

(A)
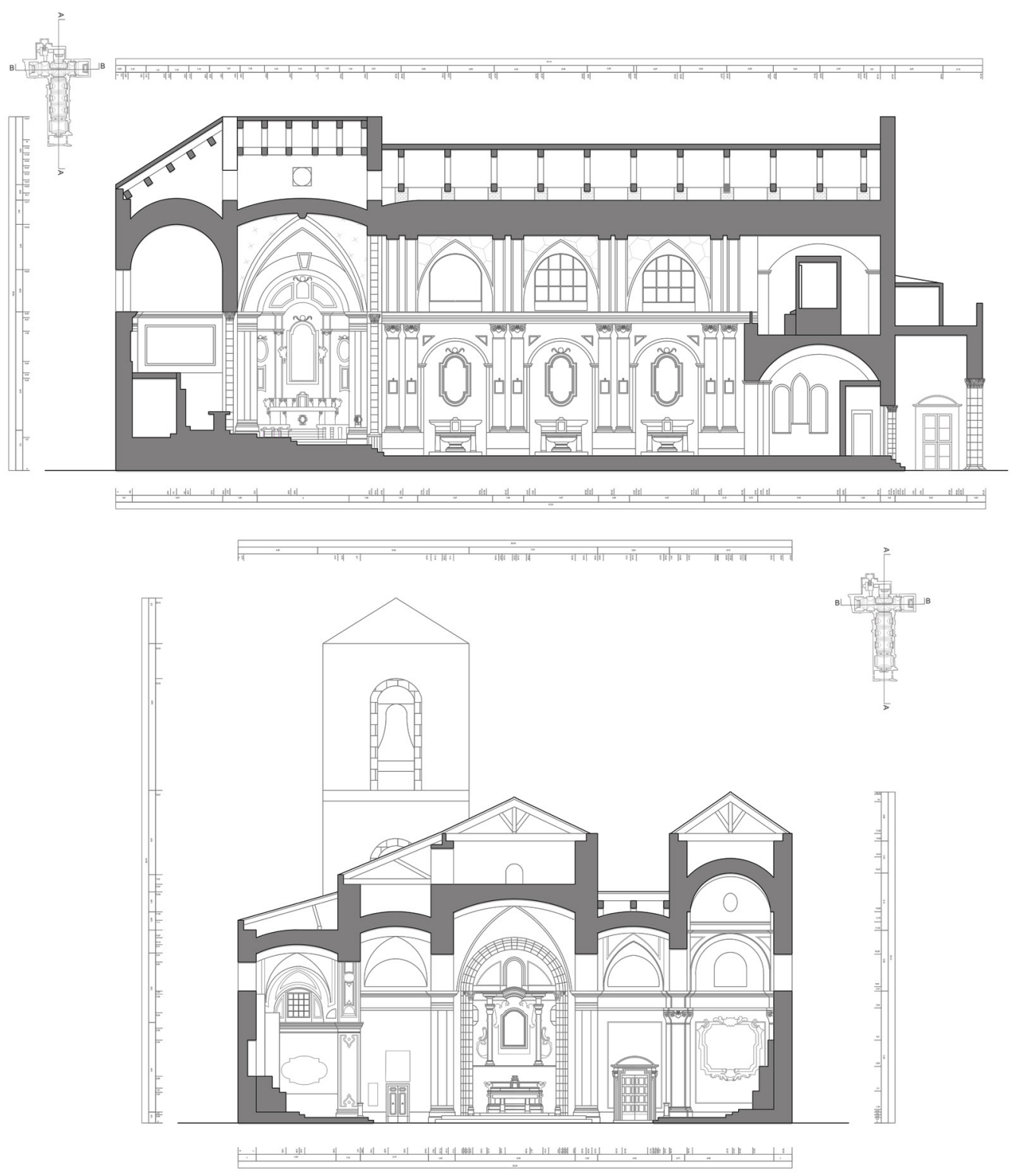
Fig. 3. Abaco di scomposizione semantica redatto per la chiesa di Sant'Antonio. Schema

a cura degli arch. A

Matascioli e M. Loffredo.

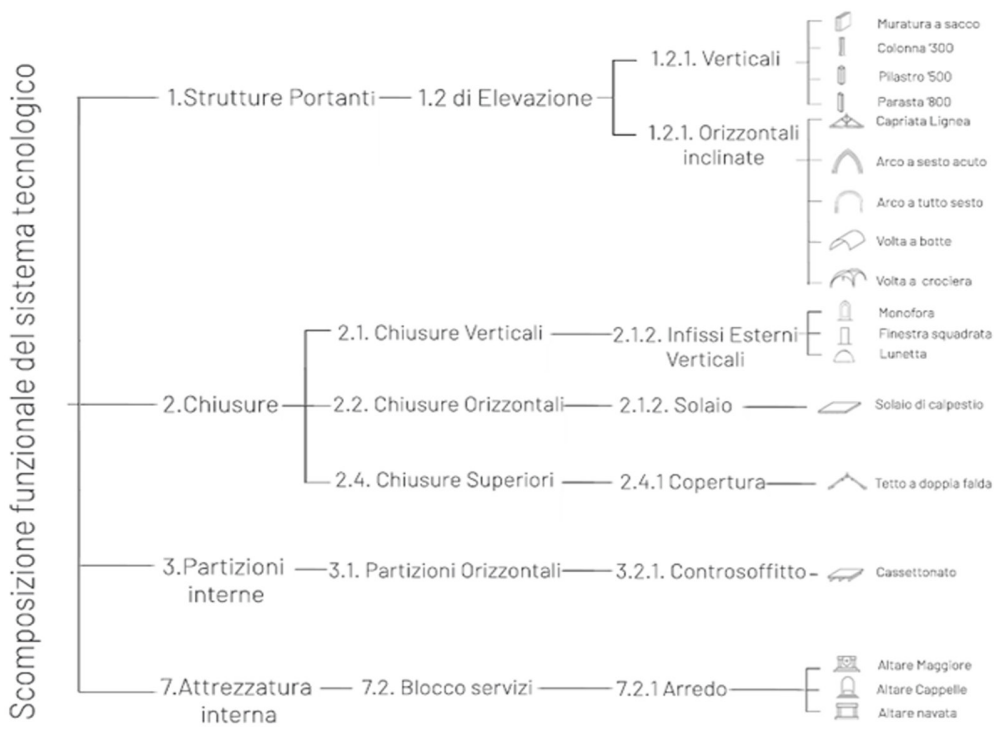

to sottoforma di nuvola di punti da cui sono stati estrapolati anche elaborati bidimensionali di tipo tradizionale (fig. 2), è convogliata nella successiva fase di modellazione parametrica di tipo HBIM in ambiente Revit.

Per la costruzione del digital twin, è stato necessario, come oramai ben noto, interrogarsi su quali fossero le unità minime ossia gli elementi significativi in cui è possibile scomporre semanticamente il manufatto. In linea con ricerche condotte con rigore sul tema [Bianchini 202 I; Scandurra 20 17], è stato redatto un albero di scomposizione semantica che individuasse, anche in ossequio alla UNI8290 del 198I, per la chiesa di Sant'Antonio le forme significanti da restituire come smart-objects in BIM (fig. 3). È evidente però che il processo di scomposizione semantica è sempre condotto di pari passo con la scelta del LOD. Le

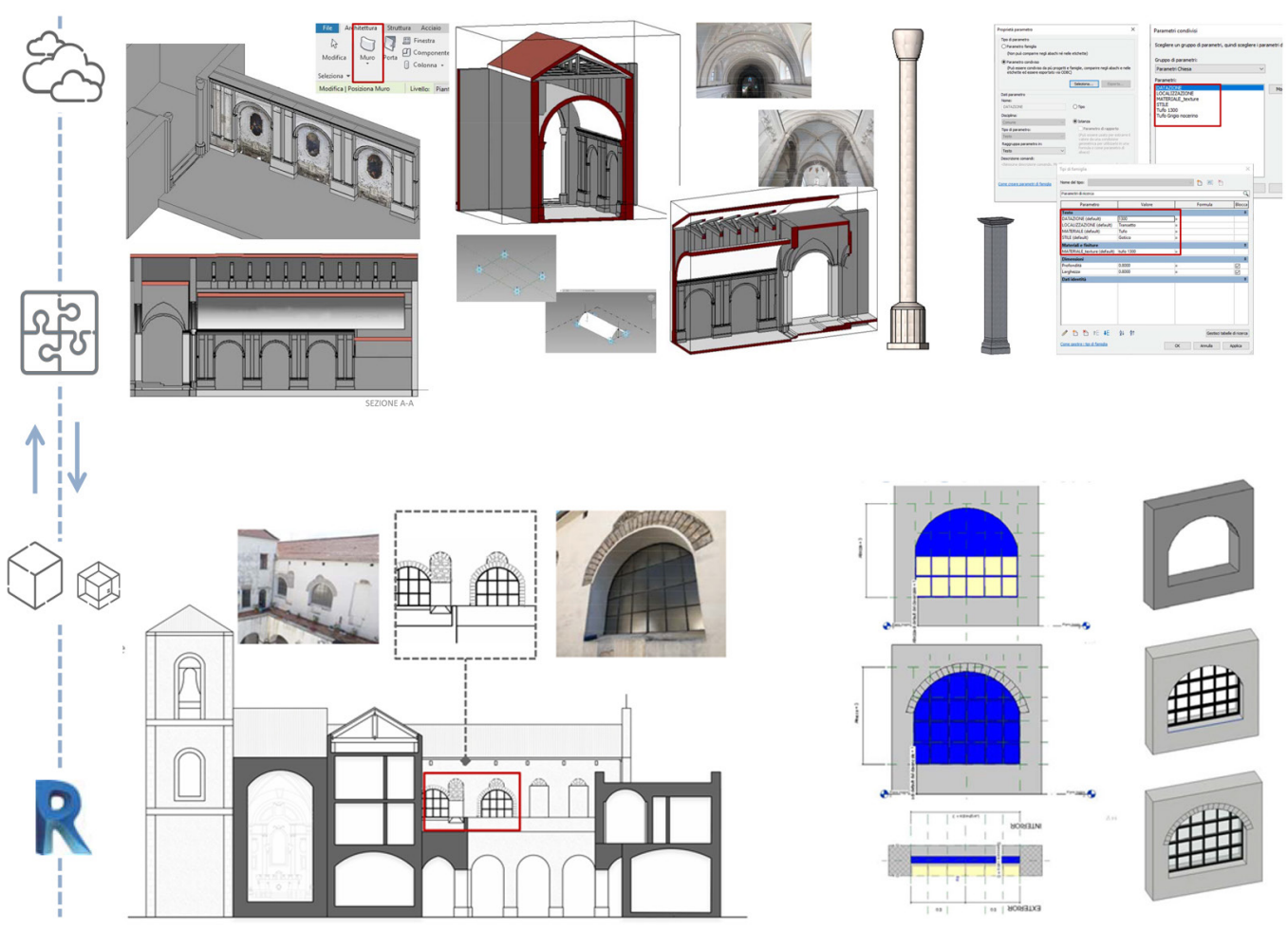
caratterizzazione degl smart-objects della smart-objects della famiglie realizzate ad hoc per il tessuto storico. Composizione a cura degli arch. A. Matascioli e M. Loffredo. 
due fasi si influenzano, infatti, reciprocamente in quanto la suddivisione in macro e micro-elementi è connessa al livello di dettaglio con cui si vuol rappresentare la geometria e allo stesso tempo questo è dipendente dagli attributi e caratterizzazioni informative $(\mathrm{LOI})$ che si vuole e che si possono collegare. Scelto, per il caso studio in oggetto, un LOD300, la fase di modellazione del dato ha richiesto la predisposizione di famiglie specifiche per gli elementi propri della fabbrica storica laddove non presenti nelle librerie precostituite. Beneficiando degli studi sull'argomento [Bagnolo 202 I; Allegra 2020; Di Luggo 20 I8], sono state realizzate famiglie di sistema e famiglie caricabili rispettivamente per muri, solai, sistemi voltati a crociera, finestre lunettate, colonne gotiche e pilastri cinquecenteschi. Oltre alla geometria, nella definizione degli oggetti parametrici sono state considerate anche proprietà di istanza legate a localizzazione, datazione, materiale ed epoca essendo tali attributi il cuore della verifica di interoperabilità (fig. 4).

La terza fase, di implementazione del dato, si è concentrata nella realizzazione dell'ambiente virtuale. Sfruttando il plugin Datasmith per Revit, il modello HBIM è stato importato nell'ambiente di gioco di Unreal Engine, settato usando il template collab viewer adatto alla navigazione e l'interazione per piattaforme desktop e VR. Tramite Datasmith, tutte le proprietà di istanza dei singoli elementi di Revit sono state trasformate in metadati degli Static Mesh Actors, al pari delle classiche informazioni di texture e materiale, confermando l'interoperabilità tra le due piattaforme.

Inoltre, attraverso il VPL delle blueprints è stato possibile approfondire l'interrogazione informativa di ogni elemento programmando e scegliendo il modo più intuitivo e diretto per visualizzare i metadati. Sfruttando lo scripting visivo, è stata impostata una modalità di consultazione tale che cliccando su ogni elemento che compone il modello è possibile visualizzare i suoi attributi direttamente sullo schermo, senza dover raggiungere l'apposita area del Detail browser (fig. 5). Allo stesso tempo, con le blueprints è stata progettata una simulazione animata delle evoluzioni morfologiche che la fabbrica ha subito nel tempo, sfruttando la logica del filtro delle fasi comparative presente in Revit (fig. 6).

Infine, ci si è interrogati sulle modalità con cui i dati possano essere fruiti e interrogati. In funzione delle possibili diverse esigenze di studio da soddisfare, l'investigazione ha

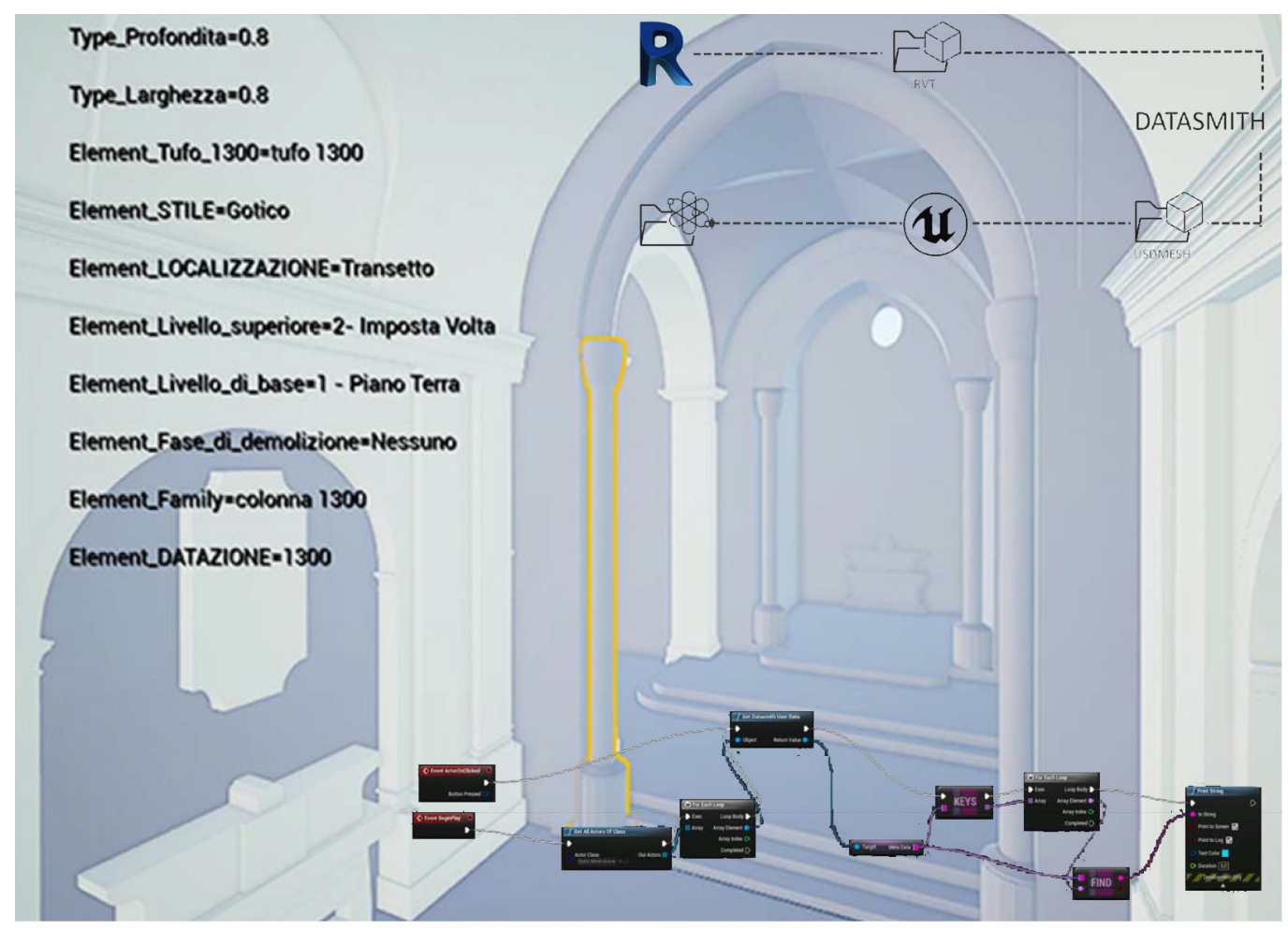


ipotizzato la possibilità di consultare i dati attraverso: I. la lettura di tavole grafiche di tipo tradizionale; 2. la fruizione del modello mediante soluzioni desktop con un approfondimento dei dati in modalità 'immersiva parziale' poiché, pur se immersi nella scena in prima persona in modalità 'giocatore', il filtro del monitor non consente la percezione totale dello spazio fisico del modello; 3. l'interazione con il modello mediante visori e manubri VR con cui sperimentare una realtà completamente immersiva e interattiva in tempo reale.

\section{Conclusioni}

La ricerca, concentrata sul caso studio del Complesso di Sant'Antonio, ha validato l'interoperabilità tra modelli intelligenti HBIM e motori di gioco, interrogati e fruiti attraverso esperienze immersive in tempo reale. Lo studio ha cercato di dare una risposta ad alcune domande basilari: I. i dati che è possibile strutturare, gestire e fruire sono metadati ossia un dato che dalla dimensione prettamente geometrica si arricchisce di livelli informativi strettamente connessi con le specificità della stratificazione del tessuto storico; 2. la interrogazione della banca dati grafico-informativa deve necessariamente essere articolata e declinata per adattarsi alla tipologia di utente e quindi, ad esempio, permettere di consultare testi e schede informative tradizionali, foto, video, manipolare modelli 3D in una visione aumentata o in prima persona, immersi in ambienti digitali; 3. la combinazione di sistemi diversi enucleati da modelli HBIM e game engine con VR apre nuovi scenari che arricchiscono la disciplina architettonica.

I modelli intelligenti mostrano di essere sempre più strumenti capaci di supportare approcci differenti per la gestione del patrimonio architettonico grazie agli elementi resi disponibili dai software del gaming. Si pensi alle potenzialità di siffatti sistemi integrati per la definizione di azioni di restauro, di manutenzione, di facility management in virtù della possibilità che offrono di simulare azioni, formare esperti per la sicurezza dei cantieri con l'interazione diretta con il modello e altro. Su questi temi evidentemente gli studi devono proseguire, sviscerando ancor più il legame possibile tra HBIM e XR per rendere le componenti oggi accostate tra loro, parte di un unico processo conoscitivo e divulgativo.
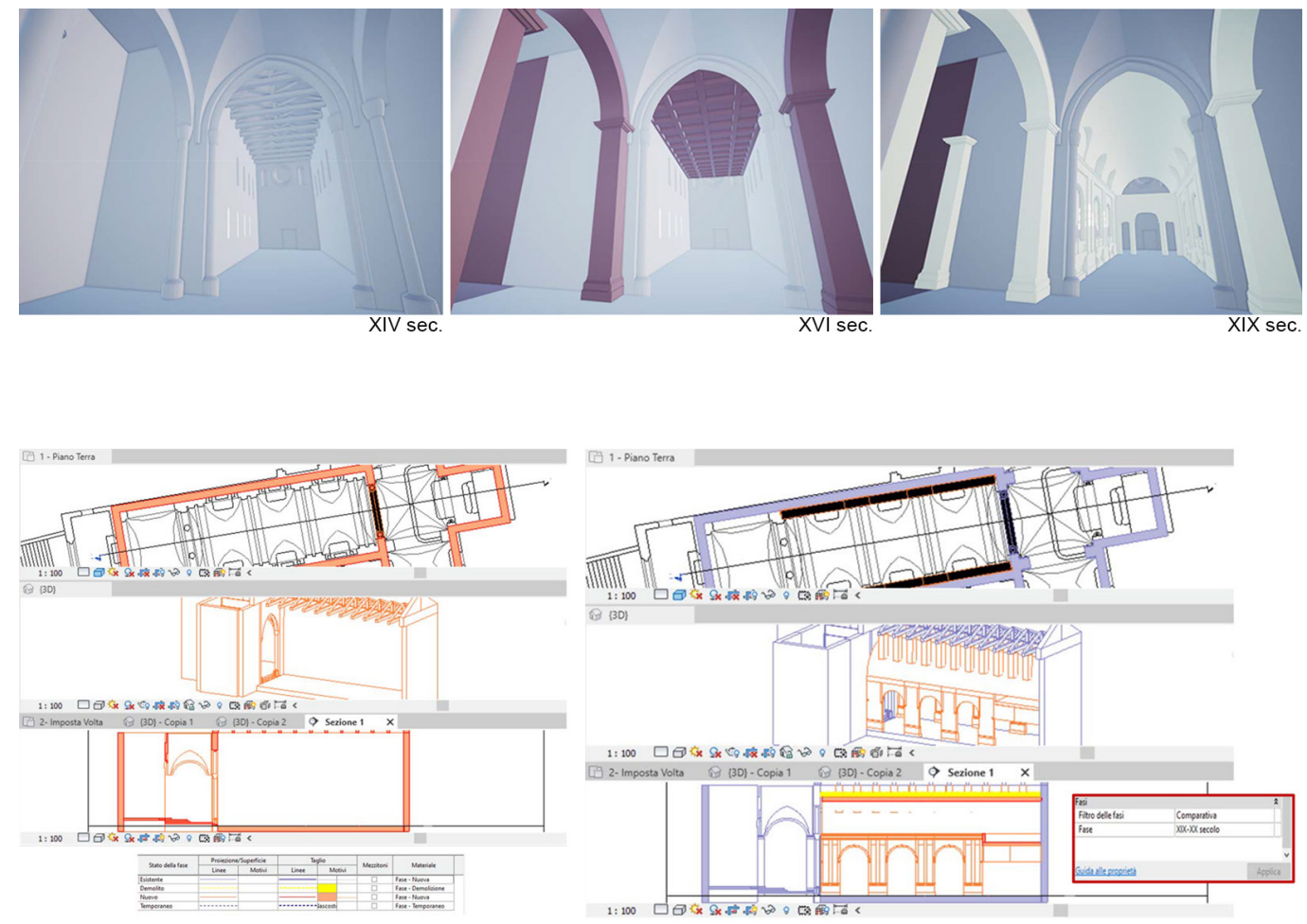


\section{Note}

[I] La ricerca è stata sviluppata come tesi di laurea degli arch. A. Matascioli e M. Loffredo, relatore prof. M. Campi, correlatore arch.V. Cera. Dipartimento di Architettura dell'Università di Napoli Federico II.

\section{Riferimenti bibliografici}

Allegra V. et al. (2020). SCAN-TO-BIM for the management of heritage buildings: the case study of the Castle of Maredolce (Palermo, Italy). In The International Archives of the Photogrammetry, Remote Sensing and Spatial Information Sciences, vol. XLIII-B2-2020, pp. | 355- I 362.

Bagnolo V., Argiolas R. (202I). Scan-to-BIM Process Versus 3D Procedural Modelling of Gothic Masonry Vaults. In C. Bolognesi D.Villa (Eds.). From Building Information Modelling to Mixed Reality, pp. 17-32. Cham: Springer.

Banfi F. (2020). HBIM, 3D drawing and virtual reality for archaeological sites and ancient ruins. In Virtual Archaelogy Review, n. I I (23), pp. 16-23.

Bianchini C., Potestà G. (202I). BIM for Built Cultural Heritage: Semantic Segmentation, Architectural Stratification and LOD of the Baptistery of San Giovanni in Florence. In: C. Bolognesi, D. Villa (Eds.). From Building Information Modelling to Mixed Reality, pp. I- 15. Cham: Springer.

Brusaporci S. et al. (2019). Per una riflessione teorico-metodologica sulla procedura HBIM di modellazione informativa dei ben architettonici. In P. Belardi (a cura di) Riflessioni. L'arte del disegno/il disegno dell'arte. Atti del $41^{\circ}$ convegno internazionale dei docenti delle discipline della rappresentazione. Perugia, 19-20-2I settembre, pp. 449-456. Roma: Gangemi Editore.

Davidson J. et al. (2020). Integration of VR with BIM to facilitate real-time creation of bill of quantities during the design phase: a proof-of-concept study. In Frontiers of Engineering Management, n. 7, pp. 396-403.

Di Luggo A. et al. (20I8). Sistemi voltati nei processi cloud to BIM. In EmplerT.Valenti G. M. (a cura di) 3D Modeling \& BIM Nuove frontiere. Workshop. Roma, I8-19 aprile, pp. 162-177. Roma: DEI.

Di Luggo A. et al. (2020). Theoretical and Methodological Implications in the Information Modelling of Architectural Heritage In Bolognesi C. M. Santagati C. (Eds.) Impact of Industry 4.0 on Architecture and Cultural Heritage, pp. 20-48. USA: IGI Global.

Empler T., Caldarone A., Fusinetti A. (2019). Leonardo da Vinci: divulgazione delle sue opere attraverso i Serious Game. In P. Belardi (a cura di). Riflessioni. L'arte del disegnolil disegno dell'arte. Atti del $41^{\circ}$ convegno internazionale dei docenti delle discipline della rappresentazione. Perugia, 19-20-2I settembre, pp. I553- I562. Roma: Gangemi Editore.

Pulcrano M. (2020). Modelli digitali interconnessi per ampliare la conoscenza e migliorare la fruizione del patrimonio costruito. In Arena A et al. (a cura di). Connettere Un disegno per annodare e tessere. Atti del $42^{\circ}$ Convegno Internazionale dei Docenti delle Discipline della Rappresentazione/Connecting. Drawing for weaving relationships. Proceedings of the 42th International Conference of Representation Disciplines Teachers, pp. 2604-2621. Milano: FrancoAngeli.

Santoni A. et al. (202I). HBIM approach to implement the historical and constructive knowledge. The case of the Real Colegiata of San Isidoro (León, Spain). In Virtual Archaelogy Review, n. 12 (24), pp. 49-65.

Scandurra S. et al. (20 I7). Modellazione H-BIM e ricostruzione delle trasformazioni del costruito storico. In Dienne, n. I, pp. 7- I9.

\section{Autore}

Valeria Cera, Università degli Studi di Napoli Federico II, valeria.cera@unina.it

Per citare questo capitolo: Cera Valeria (202I). L'interoperabilità tra software BIM e gaming. Una sperimentazione aperta per l'architettura storica/ Interoperability between BIM and Gaming Software. An Open Experimentation for Historical Architecture. In Arena A. Arena M. Mediati D, Raffa P (a cura di). Connettere Un disegno per annodare e tessere Linguaggi Distanze Tecnologie. Atti del $42^{\circ}$ Convegno Internazionale dei Docenti delle Discipline della Roppresentozione/Connecting. Drowing for weoving relationship.Longug Conference of Representation Disciplines Teachers. Milano: FrancoAngeli, pp. 2181-2198. 


\title{
Interoperability between BIM and Gaming Software. An Open Experimentation for Historical Architecture
}

\author{
Valeria Cera
}

\section{Abstract}

The paper presents a research conducted as part of a degree thesis on the extremely contemporary theme of the interoperability between HBIM models and software deriving from gaming, for their interrogation and use.Through the implementation of a protocol that marks the progressive activities from data collection to their use, tested on the case study of the Sant'Antonio complex in Nocera, the research has validated the interoperability between the most accredited BIM authoring software (Autodesk Revit) and the Unreal Engine, the most powerful game engine in the industry today. The interest of the study is expressed in the desire to answer three basic questions: I. What are the potential resources among the large quantity and variety of information that characterize the stratified historical heritage that it is necessary to collect and disseminate, according to the objectives? 2. How to structure information according to needs? 3. Why the combination of the systems investigated constitutes a resource in the process of heritage knowledge, analysis and communication?

Keywords

interoperability, informative models, HBIM, VR, Unreal Engine.

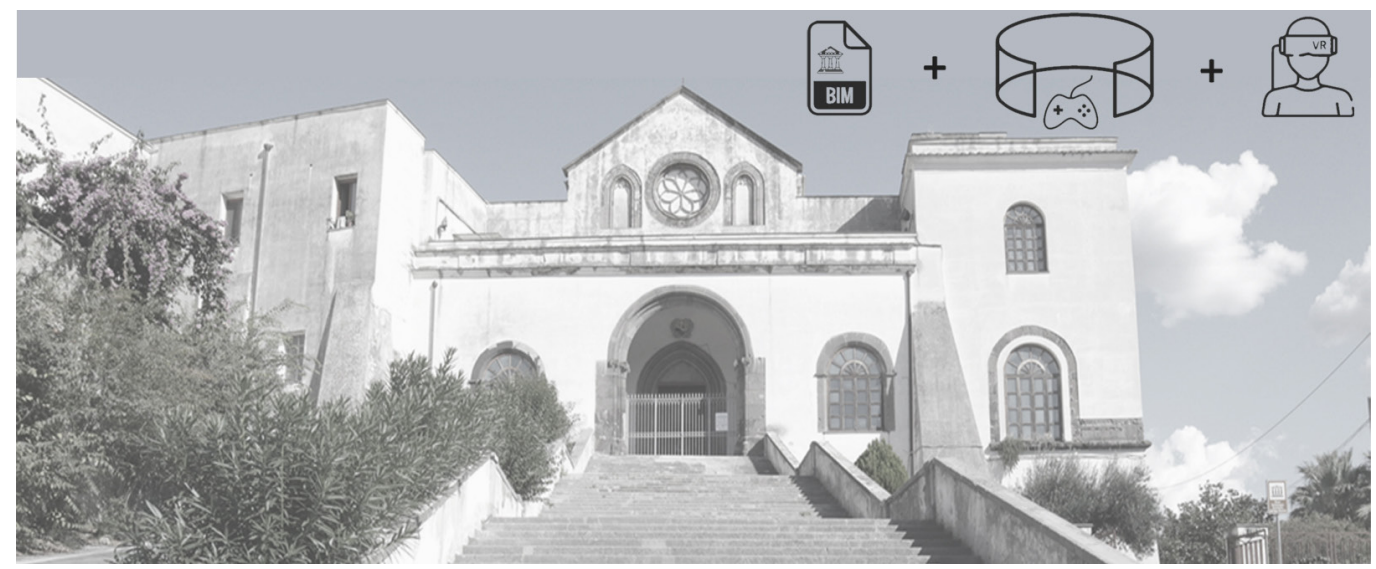




\section{Introduction}

According to data reported by Unesco, $70 \%$ of the national territory is classified as a Historical Heritage, which makes Italy the country with the largest cultural heritage in the world. These data are not intended to be a trivial advertising report but show how necessary it is for all the actors who exercise their skills in the field of Cultural Heritage to know, preserve, manage and disseminate the heritage as a testimony of our civilization.

The methodological development of Heritage-BIM models is based on this awareness, conceived as information systems that structure the quantity of heterogeneous information that specifically connotes the historical fabric around parametric smart objects. While there is widespread awareness of the difficulties of coding specific smart-objects for the characterization of historical artefacts [Santoni 2021; Brusaporci 2019]; on the other hand, the possibilities underlying the establishment of data archives capable of collecting, organizing and managing multiple levels of knowledge, linked to the digital spatial expression of the built, are evident.

At the same time, the exponential development of industry 4.0 and the increasingly widespread familiarity with digital tools, has transferred the use of techniques of Extended-Reality also to the domain of the $\mathrm{CH}$ so that the same BIM platforms have implemented plugins for support visualizations in $A R$ and VR. In this way, the application of XR to HBIM models [Banfi 2020; Davidson 2020; Empler 20 I9] has become a research segment on which numerous studies are focusing, aimed at identifying the most suitable processes for viewing and querying the information accompanying the geometry of the digital twin. The review of the specific literature highlights that the result offered by these applications is not always consistent with the initial objectives since to make the vision of digital content fluid, the XR systems require a geometric and therefore graphic simplification of the model with consequent potential loss of the associated information content. In addition, the interaction modes offered are often basic and not customizable.

For these reasons, the use of programs deriving from the world of gaming is becoming increasingly widespread to benefit from the high level of photorealism of digital scenes as well as the various possibilities of giving a personal and non-standardized character to interactivity [Pulcrano 2020; Di Luggo 2020]. Game engines, such as Unity or Unreal Engine, are systems that contain graphic, physical and artificial intelligence devices capable of simulating reality with an adherence to the physical and perceptual processes that characterize it such as to sometimes forget the very boundary. labile between the simulated world and the real world. Furthermore, unlike traditional rendering engines, they make possible animations, simulations, advanced interactions thanks to the design - using common programming languages - of the scene that will no longer be static but made dynamic. This aspect is fundamental because, according to the objectives that lead a user to approach an asset of the built heritage and its digital clone, the levels of 'deliverable' knowledge must necessarily be structured in such a way as to adapt to the needs and requests of the interlocutor who is not necessarily a specialist.

From these premises the research presented [I] was born, focused on verifying the real interoperability between HBIM models structured in Autodesk Revit, among the most accredited BIM authoring programs, and the game engine Unreal, today the most powerful in the sector.

Through the implementation of a protocol that marks the progressive activities from data collection to their use, tested on the case study of the Sant'Antonio complex in Nocera, the study tries to answer three basic questions: I. What are the potential resources among the large quantity and variety of information that characterize the stratified historical heritage that it is necessary to collect and disseminate, according to the objectives? 2. How to structure information according to needs? 3. Why the combination of the systems investigated constitutes a resource in the process of heritage knowledge, analysis and communication? 

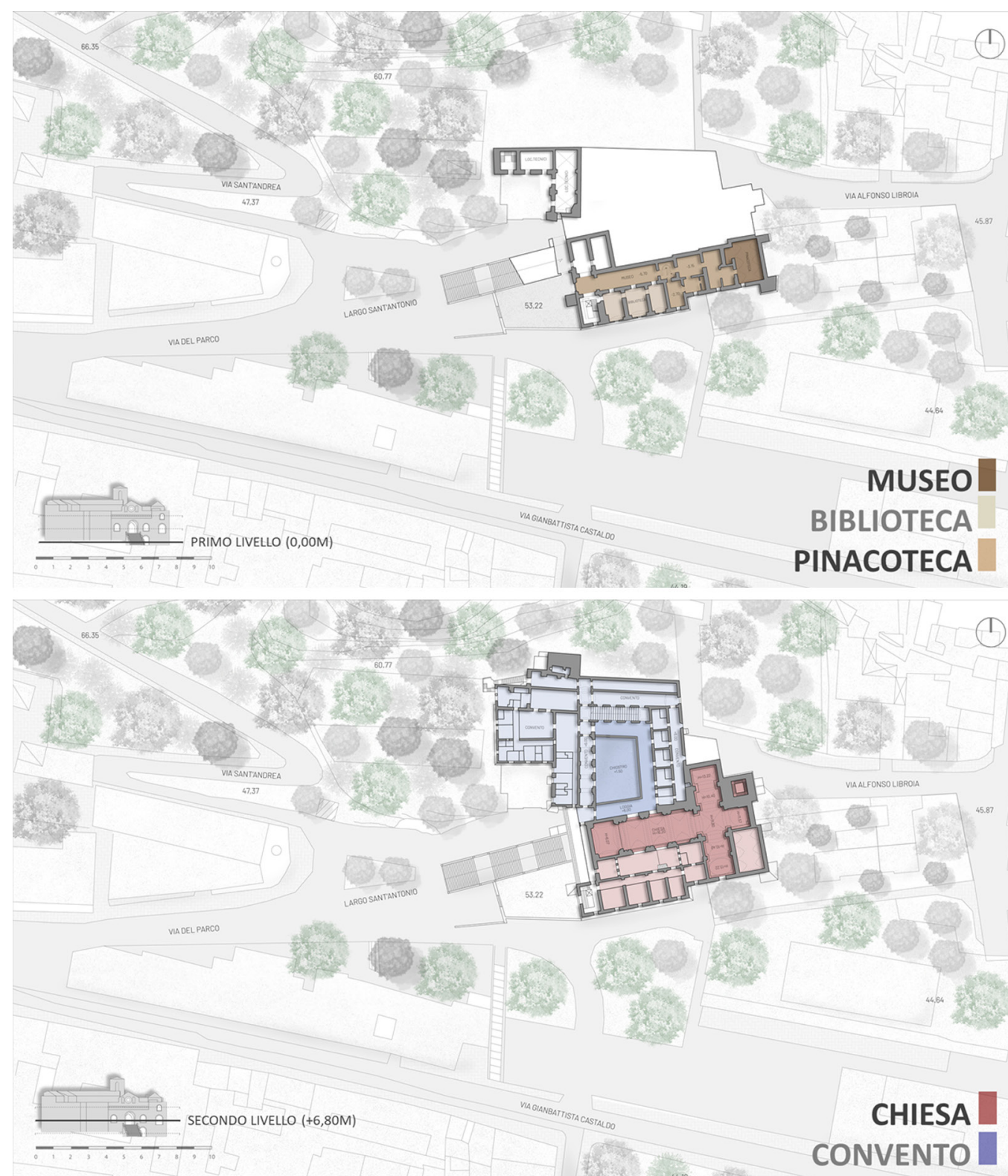

Fig. I.The complex of Sant'Antonio in Nocera, today. Drawings by arch. A. Matascioli and $M$.

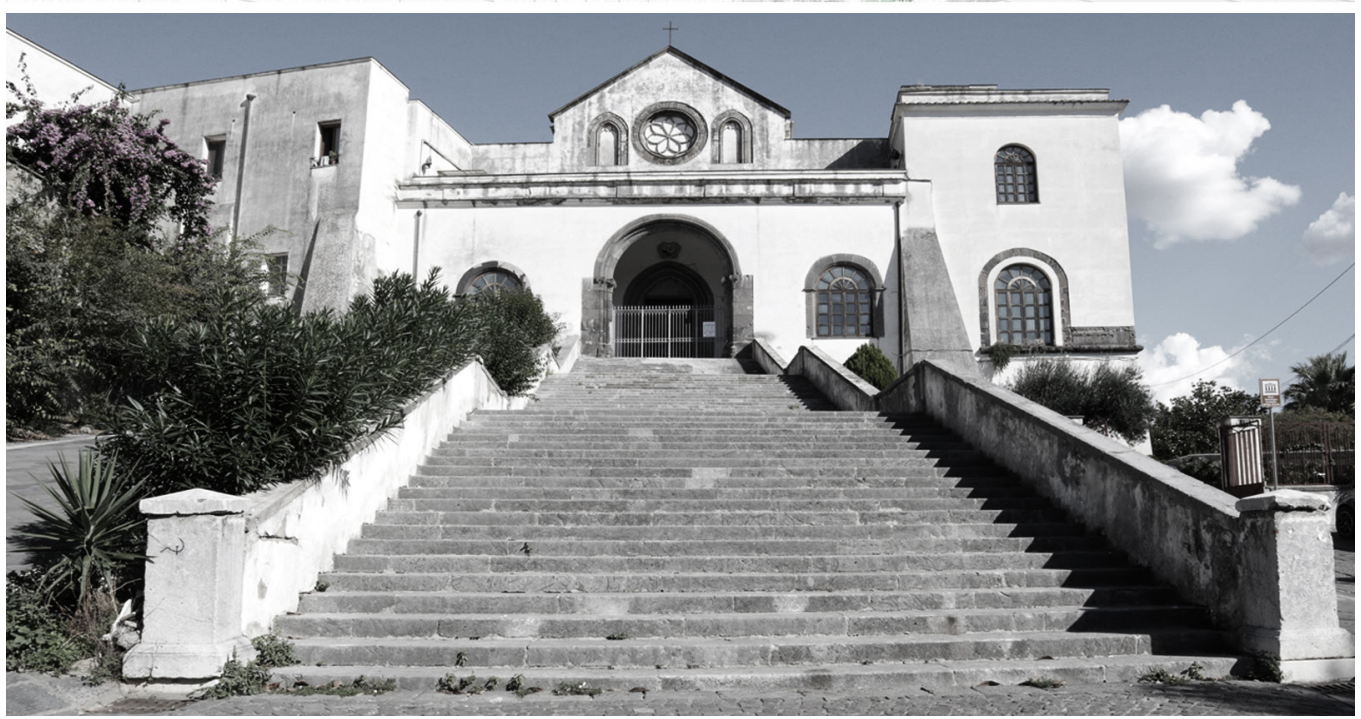




\section{Case study: the Sant'Antonio complex in Nocera}

Located in the municipality of Nocera Inferiore (SA), the Sant'Antonio complex stands at the foot of the Park Hill, falling into the Casale della Pietraccetta district whose development over time is closely linked to the presence of the religious complex.

The foundation of the building, inserted in a prestigious architectural context given the presence in the immediate vicinity of the most important and ancient emergencies of the city, has fourteenth-century origins. The first structure was built between I 256 and I 290 at the behest of the Filangieri family and remained roughly the same until the first restoration (I563-1580) and the first extensions that took place between the fifteenth and seventeenth centuries commissioned by the Carafa family. The most significant transformations took place following the suppression of the Order with the conversion of the convent into a barracks with the Royal Decree of I 808. With the advent of the Great Wars, the complex continued to maintain its strategic role and to undergo numerous changes. With the return of the monks in 1951, it returned to play its role as a religious and cultural centre, also welcoming new functions such as the Agro Nocerino library. The monks started a series of restorations with the aim of eliminating the alterations that have occurred over time. Due to the 1980 earthquake, the complex suffered serious damage to the roofing system. The tragic event, however, gave rise to a series of consolidation and restoration operations which made the ancient traces layered and buried over time resurface.

Currently the complex is spread over several levels.

The floor at street level includes the museum, the library and the picture gallery.

On the second level it is possible to distinguish:

- the church with a Latin cross plan, single nave, transept and side chapels;

- the actual convent with the priests' cells;

- the sixteenth-century cloister where the life of monks and novices takes place (fig. I).

For the validation of the research, the historical development of the complex suggested paying attention to the environment of the monastic church due to its consequent articulation and morphological variation. In fact, of all the parts of the complex, it represents the first building system and at the same time the nucleus that has undergone the most significant transformations. A real schedule that turned out to be interesting to investigate due to its aforementioned characteristics. It provides the opportunity to deal with the variety of information content that can be associated with digital models, also in relation to different historical periods, and with the most appropriate ways of communicating and consulting such multilevel data.

\section{From the HBIM model to the virtual scene interrogation}

As anticipated, the motivations of the research are the will to test the effective dialogue between systems that in themselves work autonomously and individually so as to originate a more complex 'machine' given by the 'addition' of the precise gears that compose it. Therefore, the parametric digital clone is no longer an informative 3D model that can be interrogated by experts just as $V R$ and game engines are no longer functional for simple and only visualization.

The expected result from the interconnection of these systems is a graphic-informative database, prepared for the case study, in which the three-dimensional model, structured in HBIM logic, is designed as a virtual environment. In it, the cognitive levels associated with the spatial components can be used and interrogated in a totally interactive and immersive way, which can be declined according to the user to whom it is addressed and the objectives of the query. The pursuit of the goal was conducted by setting up a workflow, applied to the church of the Sant'Antonio complex, divided into the phases of: data collection; data restitution; data implementation; use of data.

The first phase was a rich archive research accompanied by the registration of the morpho-metric data of the church conducted with an integration of traditional and image-based 


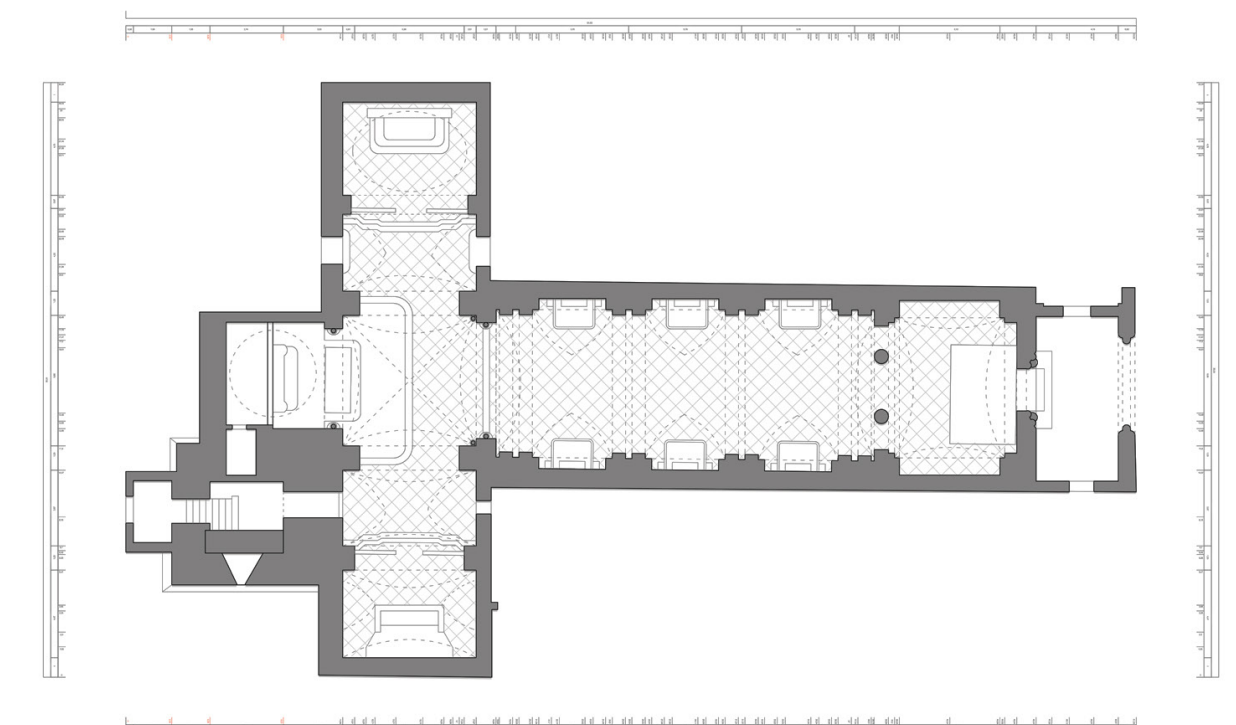

(A)

Fig. 2. Some of the twodimensional drawings

extracted from the

integrated survey and

used as a basis for

parametric modelling.

Drawings by arch.

A. Matascioli and $M$
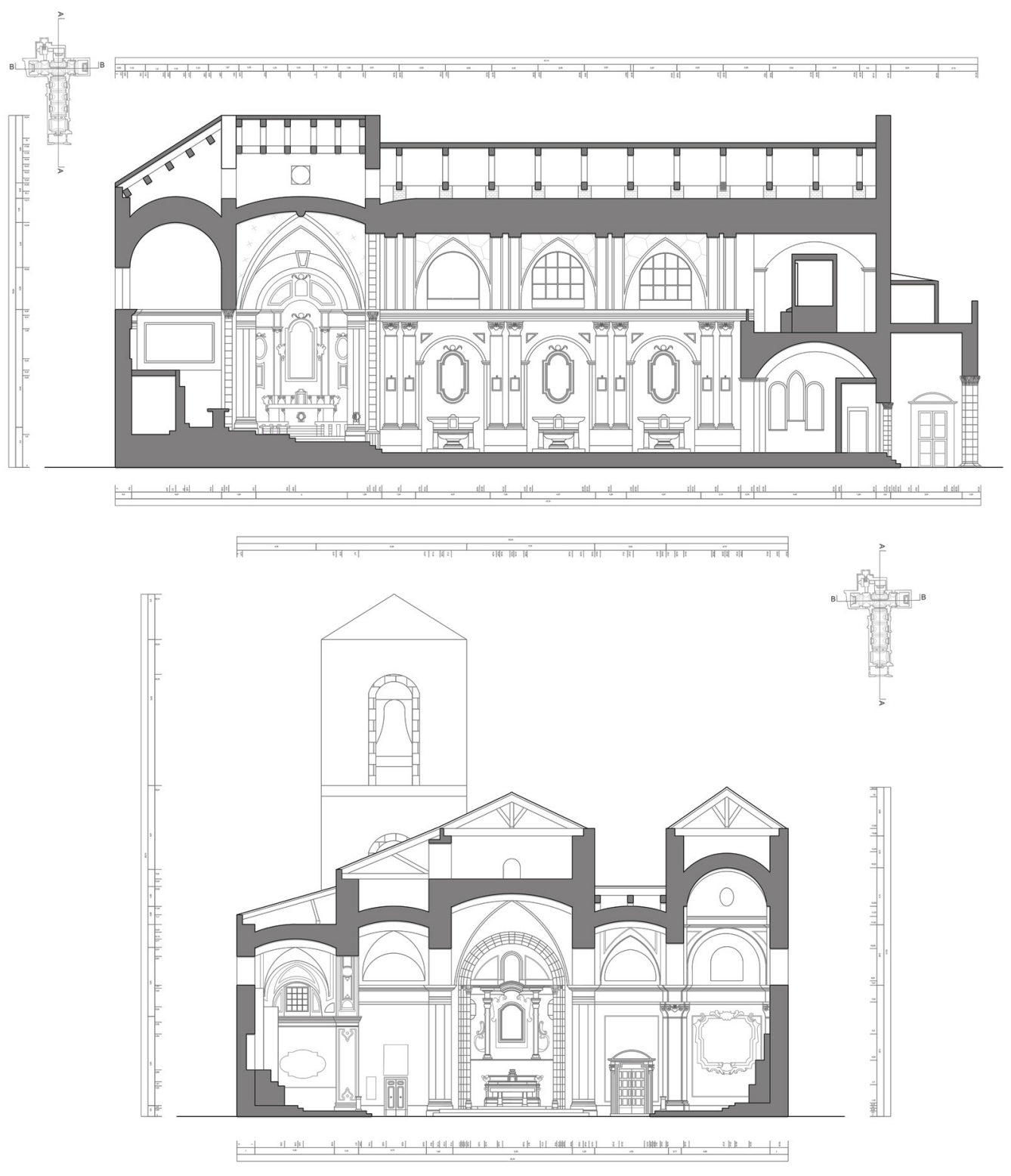
Fig. 3. Abacus of semantic segmentation drawn unt'Antonich of

the arch A Matascioli by

atascioli and

M. Loffredo.

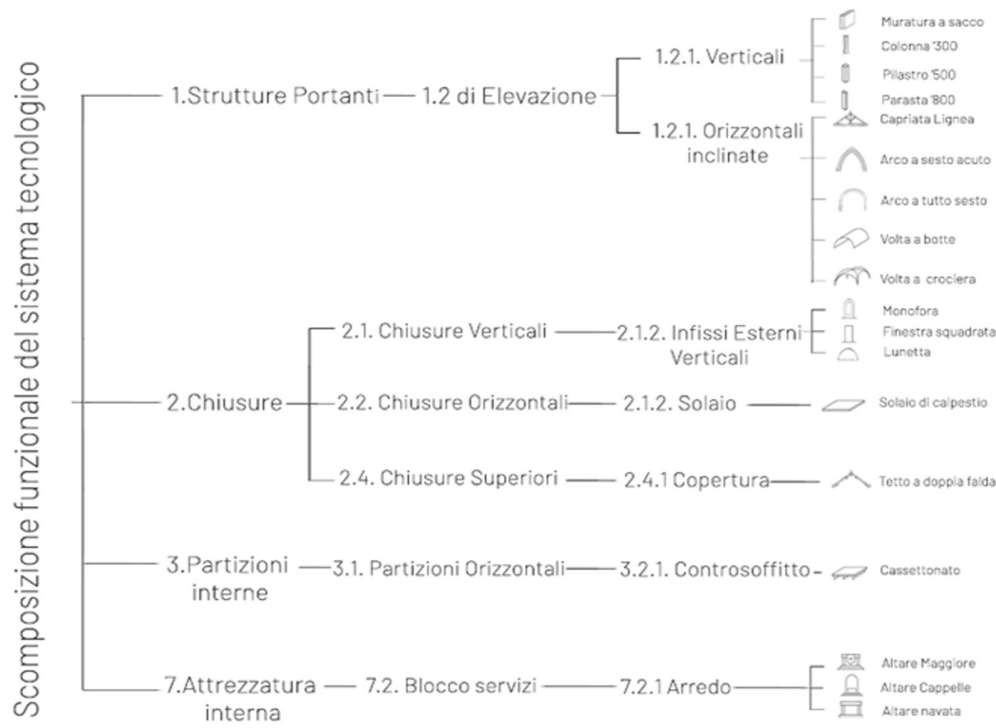

survey techniques. The critical examination of all the heterogeneous data collected was deepened with the processing in specific SFM software of a first discretized model in the form of a point cloud.Traditional two-dimensional elaborations have also been extrapolated from it (fig. 2). The materials produced were merged into the subsequent HBIM-type parametric modelling phase in Revit.

As is well known, for the realization of the digital twin, it was necessary to question what were the minimum units, the significant elements into which it is possible to semantically decompose the building. In line with research conducted with rigor on the subject [Bianchini 202 I; Scandurra 20 17], a semantic segmentation tree was drawn up that identifies the significant forms for the church of Sant'Antonio to be returned as smart-objects in BIM, also taking into

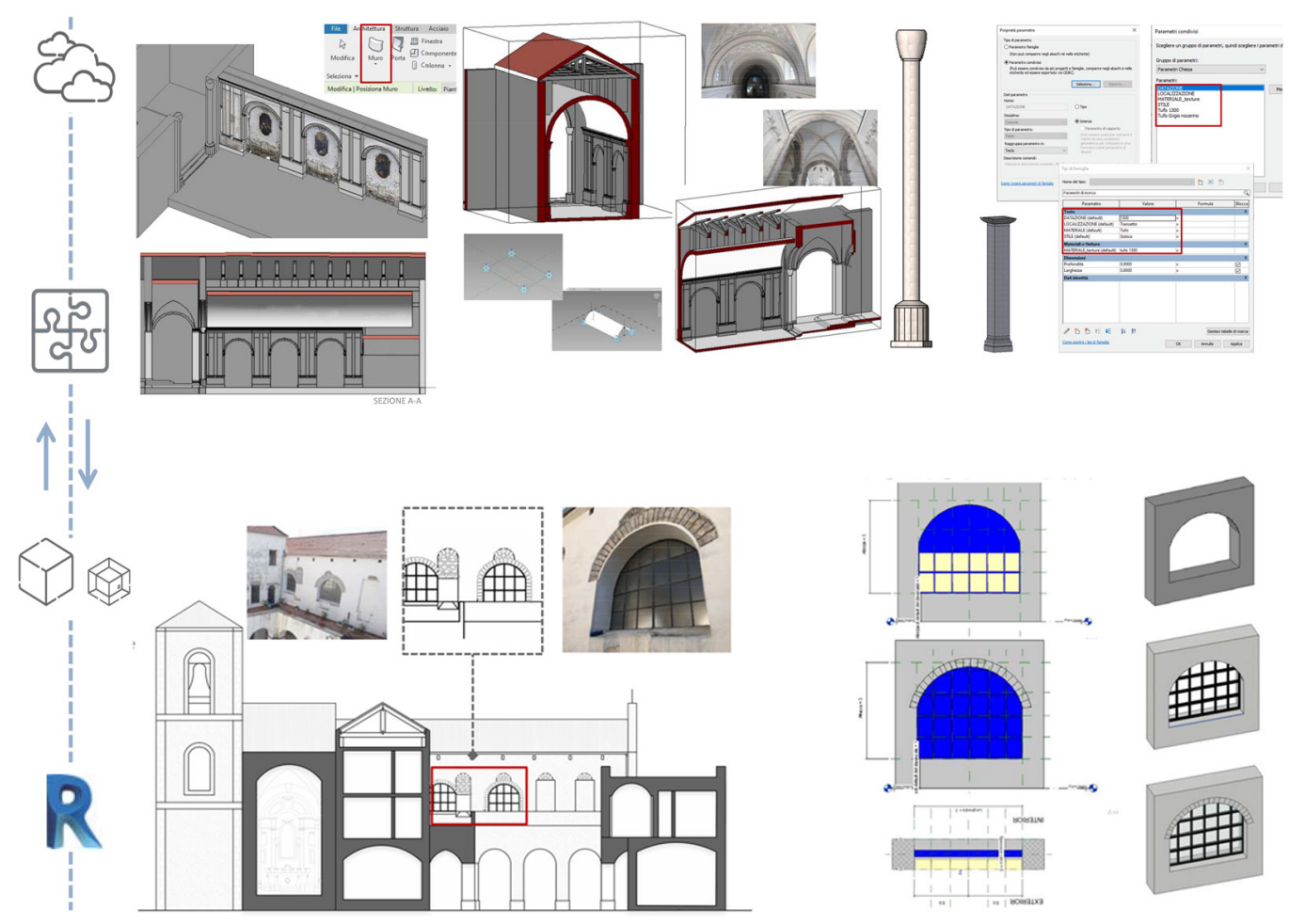

Fig. 4. Modelling and processes of the church's smart-objects, inserted in families created for the historical heritage. Image by the arch. A. Matascioli and M. Loffredo. 
consideration the UNI8290 standard of I98I (fig. 3). It is evident, however, that the semantic decomposition process is always carried out hand in hand with the choice of the LOD. The two phases influence each other, in fact, as the subdivision into macro and micro-elements is connected to the level of detail with which the geometry is to be represented. At the same time this is dependent on the attributes and informative characterizations (LOI) that you want and can connect. Having chosen a LOD300 for the case study in question, the data modelling phase required the preparation of specific families for the elements of the historical complex where not present in the pre-established libraries. Benefiting from studies on the subject [Bagnolo 202 I; Allegra 2020; Di Luggo 20 I8], system families and loadable families were created respectively for walls, slabs, cross vaults, windows with lunettes, Gothic columns and sixteenth-century pillars. In addition to geometry, instance properties linked to location, dating, material and epoch were also considered in the definition of the parametric objects, as these attributes are the heart of the interoperability check (fig. 4).

The third phase, that of data implementation, focused on the creation of the virtual environment. Using the Datasmith plugin for Revit, the HBIM model was imported into the Unreal Engine environment, set up using the collab viewer template suitable for navigation and interaction for desktop and VR platforms. Through Datasmith, all the instance properties of the individual Revit elements have been transformed into Static Mesh Actors metadata, like the classic texture and material information, confirming the interoperability between the two platforms. In addition, through the VPL blueprints it was possible to deepen the information query of each element by programming and choosing the most intuitive and direct way to view the metadata. Taking advantage of the visual scripting, a consultation mode has been set up so that by clicking on each element that makes up the model it is possible to view its attributes directly on the screen, without having to reach the specific area of the Detail browser (fig. 5). At the same time, an animated simulation of the morphological evolutions that the church has undergone over time was designed with the blueprints, using the logic of the Revit comparative phases filter (fig. 6).

Finally, the question was raised about the ways in which the data can be used and interrogated. Depending on the possible different study needs to be met, the investigation hy-

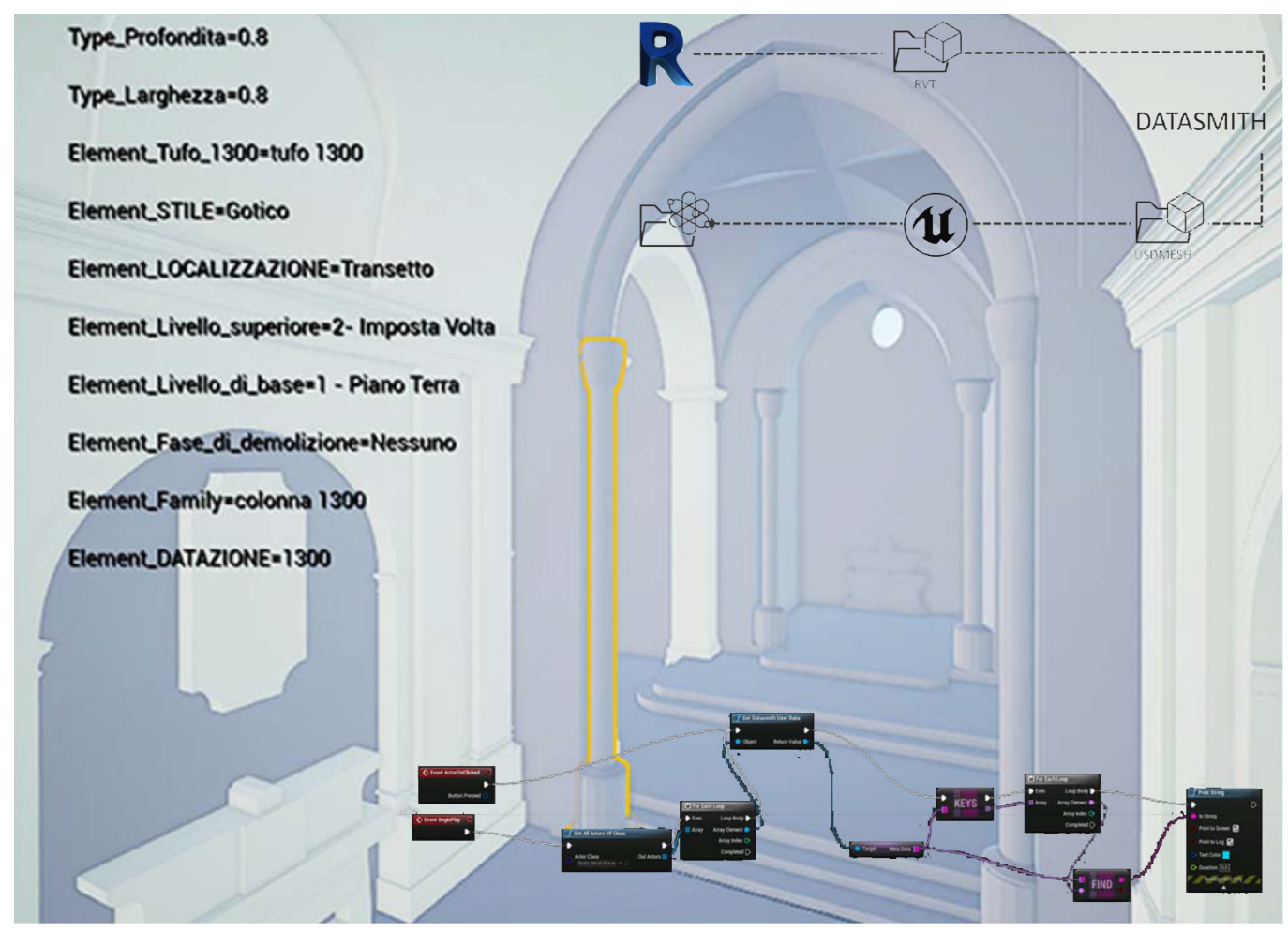


pothesized the possibility of consulting the data through: I. reading traditional drawings; 2. the use of the model through desktop solutions with an in-depth analysis of the data in a "partial" immersive mode due to the fact that, even if immersed in the first-person scene in "player" mode, the monitor filter does not allow total perception the physical space of the model; 3. the interaction with the model through VR viewers and handlebars with which to experience a completely immersive and interactive reality in real time.

\section{Conclusions}

The research, focused on the case study of the Sant'Antonio Complex, has validated the interoperability between HBIM models and game engines, interrogated and enjoyed through immersive experiences in real time. The study has tried to answer some basic questions: I. the data that can be structured, managed and used are metadata, i.e. a data that from the purely geometric dimension is enriched with information levels strictly connected with the specificities of the stratification of the built historical; 2. the query of the graphic-informative database must necessarily be articulated and declined to adapt to the type of user and therefore, for example, allow to consult traditional texts and information sheets, photos, videos, manipulate 3D models in an augmented or in first person, immersed in digital environments; 3 . the combination of different systems, HBIM models and game engine with VR, opens up new scenarios that enrich the architectural discipline.

Smart models show that they are increasingly tools capable of supporting different approaches for the management of architectural heritage thanks to the elements made available by gaming software. Think of the potential of such integrated systems for defining restoration, maintenance and facility management actions thanks to the possibility they offer to simulate actions, train construction site safety experts with direct interaction with the model and more. On these issues, studies must obviously continue, delving even further into the possible link between HBIM and XR to make the components nowadays placed side by side, part of a single cognitive and dissemination process.
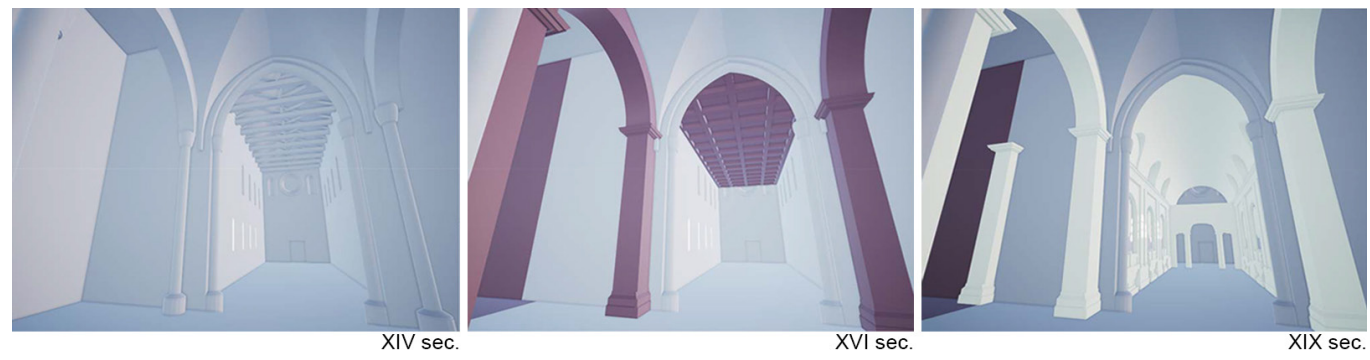

Fig. 6. Simulation of the historical transformations of the church of Sant'Antonio in a gaming environment, in accordance with the phase filter of BIM authoring software. Image by the arch. A. Matasciol
and M. Loffredo.
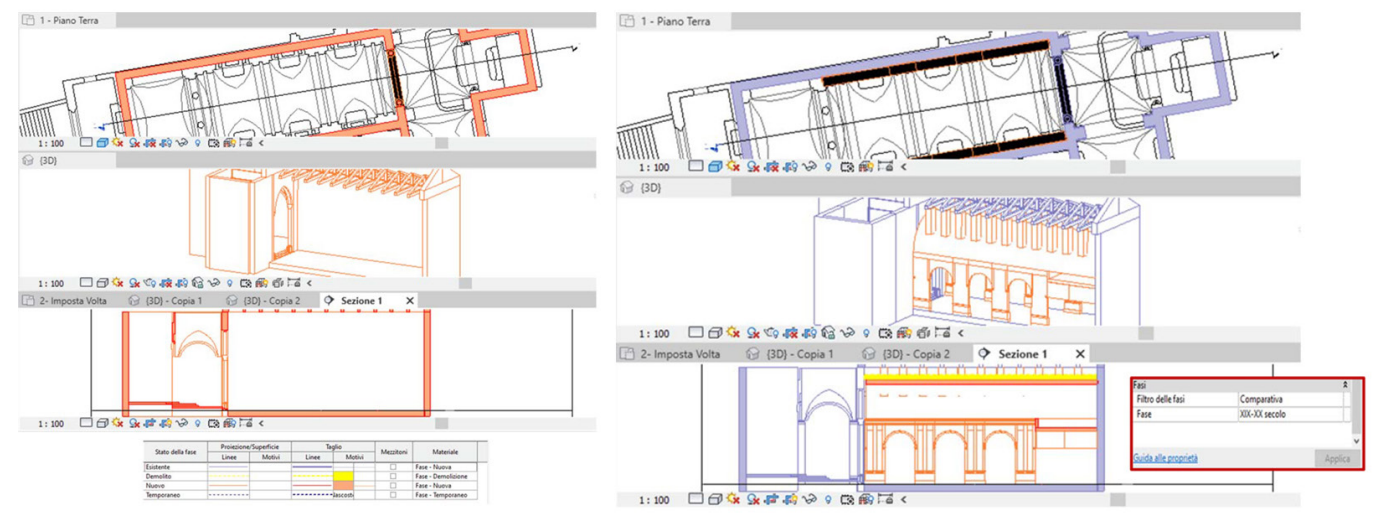


\section{Notes}

[I] The research was developed as a master's degree thesis by arch. A. Matascioli and M. Loffredo, supervisor prof. M. Campi, co-supervisor arch. V. Cera. Department of Architecture of the University of Naples Federico II.

\section{References}

Allegra V. et al. (2020). SCAN-TO-BIM for the management of heritage buildings: the case study of the Castle of Maredolce (Palermo, Italy). In The International Archives of the Photogrammetry, Remote Sensing and Spatial Information Sciences, vol. XLIII-B2-2020, pp. I 355-I 362

Bagnolo V., Argiolas R. (202I). Scan-to-BIM Process Versus 3D Procedural Modelling of Gothic Masonry Vaults. In C. Bolognesi D.Villa (Eds.). From Building Information Modelling to Mixed Reality, pp. I7-32. Cham: Springer.

Banfi F. (2020). HBIM, 3D drawing and virtual reality for archaeological sites and ancient ruins. In Virtual Archaelogy Review, n. I I (23), pp. I 6-23.

Bianchini C., Potestà G. (202I). BIM for Built Cultural Heritage: Semantic Segmentation, Architectural Stratification and LOD of the Baptistery of San Giovanni in Florence. In: C. Bolognesi, D.Villa (Eds.). From Building Information Modelling to Mixed Reality, pp. I- 15. Cham: Springer.

Brusaporci S. et al. (2019). Per una riflessione teorico-metodologica sulla procedura HBIM di modellazione informativa dei beni architettonici. In P. Belardi (a cura di) Riflessioni. L'arte del disegno/il disegno dell'arte. Atti del $41^{\circ}$ convegno internazionale dei docenti delle discipline della rappresentazione. Perugia, 19-20-2I settembre, pp. 449-456. Roma: Gangemi Editore.

Davidson J. et al. (2020). Integration of VR with BIM to facilitate real-time creation of bill of quantities during the design phase: a proof-of-concept study. In Frontiers of Engineering Management, n. 7, pp. 396-403.

Di Luggo A. et al. (20 I8). Sistemi voltati nei processi cloud to BIM. In Empler T.Valenti G. M. (a cura di) 3D Modeling \& BIM Nuove frontiere. Workshop. Roma, 18-19 aprile, pp. I62-177. Roma: DEl.

Di Luggo A. et al. (2020). Theoretical and Methodological Implications in the Information Modelling of Architectural Heritage. In Bolognesi C. M. Santagati C. (Eds.) Impact of Industry 4.0 on Architecture and Cultural Heritage, pp. 20-48. USA: IGI Global.

Empler T. Caldarone A., Fusinetti A. (2019). Leonardo da Vinci: divulgazione delle sue opere attraverso i Serious Game. In P. Belardi (a cura di). Riflessioni. L'arte del disegnolil disegno dell'arte. Atti del $41^{\circ}$ convegno internazionale dei docenti delle discipline della rappresentazione. Perugia, 19-20-2I settembre, pp. I553- I562. Roma: Gangemi Editore.

Pulcrano M. (2020). Modelli digitali interconnessi per ampliare la conoscenza e migliorare la fruizione del patrimonio costruito. In Arena A et al. (a cura di). Connettere. Un disegno per annodare e tessere. Atti del $42^{\circ}$ Convegno Internazionale dei Docenti delle Discipline della Rappresentazione/Connecting. Drawing for weaving relationships. Proceedings of the 42th International Conference of Representation Disciplines Teachers, pp. 2604-262 I. Milano: FrancoAngeli.

Santoni A. et al. (202I). HBIM approach to implement the historical and constructive knowledge. The case of the Real Colegiata of San Isidoro (León, Spain). In Virtual Archaelogy Review, n. 12 (24), pp. $49-65$.

Scandurra S. et al. (20 I7). Modellazione H-BIM e ricostruzione delle trasformazioni del costruito storico. In Dienne, n. I, pp. 7- I9.

\section{Author}

Valeria Cera, Università degli Studi di Napoli Federico II, valeria.cera@unina.it

To cite this chapter. Cera Valeria (2021). L'interoperabilità tra software BIM e gaming. Una sperimentazione aperta per l'architettura storica/Interoperability between BIM and Gaming Software. An Open Experimentation for Historical Architecture. In Arena A. Arena M. Mediati D. Raffa P (a cura di) Connettere Un disegno per annodare e tessere Linguaggi Distanze Tecnologie. Atti del $42^{\circ}$ Convegno Internazionale dei Docenti delle Discipline della Rappresentazione/Connecting. Drawing for weaving relationship. Languages Distances Technologies. Proceedings of the 42th International Conference of Representation Disciplines Teachers. Milano: FrancoAngeli, pp. 2181-2198. 